\title{
A Crystallographic, EPR and DFT Investigations of a Novel Magnetically Silent Mono-atom Acetate-Bridged Binuclear Schiff Base-Copper(II) Complex
}

\author{
Yeni Bir Manyetik Tek-atom Asetat Köprülü Schiff Bazı-Bakır(II) \\ Kompleksinin Kristallografik, EPR ve DFT ile İncelenmesi
}

\section{Research Article}

Serkan Demir ${ }^{*}$, Yusuf Yerli², Mustafa Öztürk ${ }^{3}$, Hasan Saral ${ }^{4}$, Ersin Temel ${ }^{5}$, Serkan Başgel ${ }^{6}$

'Department of Industrial Engineering, Faculty of Engineering, Giresun University, Giresun, Turkey.

${ }^{2}$ Yıldız Technical University, Science and Arts Faculty, Physics Department, İstanbul, Turkey.

${ }^{3}$ Gebze Institute of Technology, Faculty of Science, Department of Physics, Kocaeli, Turkey.

${ }^{4}$ Sinop University, Engineering Faculty, Metallurgical and Material Engineering, Sinop, Turkey.

${ }^{5}$ Department of Electricity and Energy, Vocational School of Technical Sciences, Giresun University, Giresun, Turkey.

${ }^{6}$ Laboratory Department, Middle Mediterranean Department of Customs and Trade, Ministry of Customs and Trade, Mersin, Turkey.

\section{A B STRACT}

\begin{abstract}
A recent example of one-atom acetate bridged symmetric dinuclear copper(II) complexes, Di- $\mu$-acetato-bis $\{1$ -

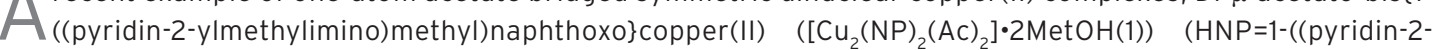
ylmethylimino)methyl)naphthol)) have been prepared and characterized by X-ray crystallography, Elemental analyses, ESI-mass, UV-Vis and IR spectroscopic techniques. Magnetic properties of the complex have been probed by EPR measurements and the presence of spin-only paramagnetism of the compound with none of significant exchange coupling has been demonstrated unlike ferro or antiferromagnetism that was otherwise observed in all other analogous structures previously reported. The existence of a trivial ferromagnetic exchange which is quantitatively ignorable has been suggested by DFT-Broken Symmetry calculations performed at crystallographically characterized experimental geometry.
\end{abstract}

\section{Key Words}

Mono-atom bridged copper(II) complex, Broken-symmetry approach, Schiff base-Copper(II) complex, EPR, DFT.

\section{öz}

\begin{abstract}
Tek-atom asetat köprülü simetrik dinükleer-bakır(II) komplekslerine yeni bir örnek olarak Di- $\mu$-asetato-bis $\{1$ ((piridin-2-ilmetilimino)metil)naftokso\}bakır(II) $\left(\left[\mathrm{Cu}_{2}(\mathrm{NP})_{2}(\mathrm{Ac})_{2}\right] \cdot 2 \mathrm{MetOH}(1)\right) \quad(\mathrm{HNP}=1$-((piridin-2-ilmetilimino) metil)naftol)) kompleksi sentezlendi ve X-ışını kristallografisi, elementel analiz, ESI-kütle, UV-Vis ve IR spektroskopik tekniklerle karakterize edildi. Kompleksin manyetik özellikleri EPR spektroskopisi tekniği ile incelendi ve daha önce çalışı Imış diğer tüm benzer yapılarda görülen ferro- ya da antiferromanyetizmden farklı olarak sadece spine bağlı paramanyetizmin varlığı, önemli bir manyetik değiş-tokuşun gözlenmemesine bağlı olarak belirlendi. Büyüklük olarak önemsenmeyecek derecede küçük olan ferromanyetik etkileşimin varlığı ise kristal geometride gerçekleştirilen DFT-kırılmış simetri hesaplamaları ile belirlendi.
\end{abstract}

\section{Anahtar Kelimeler}

Tek-atom köprülü bakır(II) kompleksi, Kırılmış-simetri yaklaşımı, Schiff bazı-bakır(II) kompleksi, EPR, DFT.

Article History: Received: Mar 9, 2016; Revised: Jun 26, 2016; Accepted: Sep 20, 2016; Available Online: Apr 1, 2017.

DOI: 10.15671/HJBC.2017.136

Correspondence to: S. Demir, Department of Industrial Engineering, Faculty of Engineering, Giresun University, Giresun, Turkey. 


\section{INTRODUCTION}

inuclear copper(II) complexes, the simplest examples of magnetically coupled systems with one unpaired electron per one metal centre, have been extensively studied for three decades with attempts to probe structuremagnetism relations taking into account broad existence of binuclear copper(II) centres in biologically relevant environments [1-4]. Both intra or intermolecular magnetic exchange phenomena are of interest within the theory of molecular magnetism, copper(II)-carboxylates as the foremost class of magnetically coupled systems explored until now have extremely allowed to generate great number of diverse magnetostructural informations and correlations [5-18]. As of copper(II)-acetate hydrate which is the first binuclear copper(II) complex where the intramolecular magnetic exchange coupling was first recognized $[18,19]$, almost countless examples of bridged copper(II)-carboxylates displaying different types of magnetic exchanges with various bridging modes of highly versatile carboxylate linkers appeared since then in the literature [6-8,10,13-16,20-22]. In these complexes, the most common observed bridging modes are syn-syn, anti-anti, syn-anti and monoatomic bridges each demonstrating varying magnetic superexchange pathways $[8,23]$. On the other hand, the number of monoatomic acetate-bridged symmetric binuclear copper(II) complexes in the presence of ancillary ligands are still relatively limited and all of them studied so far were found to display weak ferro or antiferromagnetic coupling [24-29]. In case of the incorporation of co-ligands in order for the preparation of oneatom bridged binuclear complexes, the use of appropriate ones serving as complementary structural template is mandatory. Schiff bases with $\mathrm{N}_{2} \mathrm{O}$ donor sites were demonstrated to be the most sensible choice for this purpose based on the related studies previously reported [27-31] since multidentate Schiff base ligands form stable complexes with almost all metals and readily adopt the conformational variations taking place depending on the bridging co-ligands. Symmetric binuclear copper(II) complexes are topologically divided into two main categories namely, planar a and, parallel-planar b as depicted in Scheme 1.

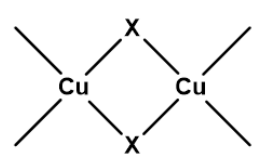

a

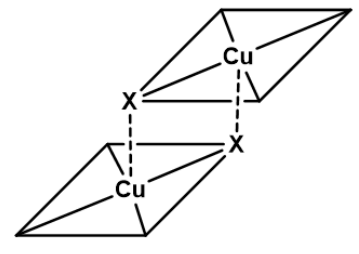

b

\section{Scheme 1}

In the most cases where tridentate $\mathrm{N}_{2} \mathrm{O}$ Schiff base ligands are incorporated, square-pyramidal one-atom bridged complexes of type $b$ are mainly obtained [24-30] and in this array, Schiff base ligands resides in basal plane while one bridging atom occupies the axial position of one monomeric unit and the other locates in basal plane of the same unit. This type of dimers display weak exchange coupling, often antiferromagnetic, as expected since only one atom participates bridging mode. In case of our report here however, we described synthesis of a new $[\mathrm{Cu}(\mathrm{Ac})(\mathrm{NP})]_{2}$ complex of type $b$ using a flexible tridentate $\mathrm{N}_{2} \mathrm{O}$ Schiff base HNP and characterized the complex by $x$-ray crystallography, ESI-MS, and elemental analyses. This is a rare example of magnetically silent copper(II) complex of type $b$ to the best of our knowledge. Exchange interaction of the title complex was examined through EPR measurements. The intramolecular exchange coupling of the complex was also evaluated by DFT-Broken Symmetry (BS) approximation [32,33] and the experimental geometry was directly used for the calculations because it is well known that very small variations in the experimental geometry such as a few degrees of change in bond angle at bridging atom can change even the type of magnetic exchange. The results of BS calculations successfully supported the observed exchange behaviour of the title complex.

\section{EXPERIMENTAL}

\section{Materials and Measurements}

All reagents were purchased from commercial suppliers and used as received. Elemental analyses were determined with LECO CHNS932 elemental analyser (USA). IR spectrum was recorded on a Bruker Vertex-80V ATR-FT-IR 
spectrophotometer (Germany) in 4000-400 $\mathrm{cm}^{-1}$ range. UV-Vis spectra were recorded on a Unicam UV2 UV-Vis spectrometer (USA) within 200-800 nm range, in methanol medium. ESIMS spectrum were recorded in methanol on an AB SCIEX QTRAP ${ }^{\circledR} 5500$ LC/MS/MS System Mass spectrometer (USA). The EPR powder spectrum was recorded with JEOL X3 series $X$-band ESR spectrometer (Japan), with $100 \mathrm{kHz}$ magnetic field modulation.

\section{Synthesis of 1}

2-hydroxynaphthaldehyde $(0700 \mathrm{~g}, 4.07 \mathrm{mmol})$ was dissolved in $25 \mathrm{ml}$ absolute ethanol, and to this stirring solution 2-picolylamine $(0.432$ $\mathrm{g}, 4.0 \mathrm{mmol}$ ) was dropwise added. The mixture was stirred for $2 \mathrm{~h}$ at $50^{\circ} \mathrm{C}$ and cooled to room temperature. The resulting bright yellow Schiff base solution was gradually added to a $20 \mathrm{ml}$ ethanolic solution of copper(II) acetate hydrate ( $0800 \mathrm{~g}, 4 \mathrm{mmol}$ ) and the color of the mixture was turned into dark brown. After further stirring the solution for $10 \mathrm{~min}$, the colour turned into dark green and remained firm despite further stirring for several hours. This final solution was left in the dark for recrystallization and dark green crystals suitable for X-ray diffraction was formed after several days. Yield: 55\%. Anal. Calc. C, 58.20; N $6.96 ; \mathrm{H}, 4.47 \%$. Found: $\mathrm{C}, 55.41 ; \mathrm{N}, 6.76 ; \mathrm{H}, 4.87 \%$. IR $\left(\mathrm{KBr}, \mathrm{cm}^{-1}\right): 3040 v_{\text {arom }}(\mathrm{CH}) ; 1619 v(\mathrm{C}=0) ; 1588$ $v(\mathrm{C}=\mathrm{N}) ; 1538 v_{\text {asym }}(\mathrm{COO}-) ; 1421$ vsym(COO-). ESI-MS (m/z, \%): 772(1+4H) 35\%; $585\left(\left[\mathrm{Cu}(\text { napc })_{2}\right]+2 \mathrm{H}\right)$ $7 \% ; \quad 510 \quad\left(\left[\mathrm{Cu}_{2}(\mathrm{AcO})_{2}(\mathrm{napc})\right]+3 \mathrm{H}\right) \quad 15 \% ; \quad 324.2$ ([Cu(napc) $\left.)^{+}\right]$) $100 \%$ (see S2 for mass spectra in supporting information).

\section{X-ray Crystallography}

Intensity data for 1 were collected using STOE IPDSII area detector diffractometer (Mo Ka radiation, $\lambda=0.71073$ ) at $293 \mathrm{~K}$. The structure was solved by direct method and refined by a full matrix leastsquares method on F2 [34]. All non-hydrogen atoms refined anisotropically and all hydrogen atoms placed geometrically on their carrier atom when possible and refined with a riding model. The details of data collection, refinement and crystallographic data are summarized in Table 1.
Table 1. Crystal data and structure refinement parameters for (1) and (2) complexes.

\begin{tabular}{lc}
\multicolumn{1}{c}{ Complex } & (1) \\
\hline Formula & $\mathrm{C}_{38} \mathrm{H}_{32} \mathrm{~N}_{4} \mathrm{O}_{6} \mathrm{Cu}_{2}$ \\
\hline Molecular weight $(\mathrm{g} / \mathrm{mol})$ & 767.76 \\
\hline Temperature $(\mathrm{K})$ & $293(2)$ \\
\hline Wavelength $(\AA)$ & 0.71073 \\
\hline Crystal system & Monoclinic \\
\hline Space Group & $\mathrm{P} 21 / \mathrm{c}$ \\
\hline & $\mathrm{a}=13.0179(6) \AA$ \\
\hline Dimensions & $\mathrm{b}=8.6785(3) \AA$ \\
\hline $\mathrm{C}$ & $\mathrm{c}=18.5488(10) \AA$ \\
\hline Volume $\left(\AA^{3}\right)$ & $\beta=116.370(4)$ \\
\hline $\mathrm{F}(000)$ & $1877.50(15)$ \\
\hline Dcalc. $\left(\mathrm{mg} / \mathrm{mm}^{3}\right)$ & 2 \\
\hline (mm $\left.{ }^{-1}\right)$ & 1.468 \\
\hline
\end{tabular}

\begin{tabular}{lc}
$\begin{array}{l}\text { range for data } \\
\text { collection }\left({ }^{\circ}\right)\end{array}$ & $2.29-26.50$ \\
\hline Reflections collected & 3897 \\
\hline Independent reflections & 2789 \\
\hline Absorption correction & Integration \\
\hline Goodness-of-fit on $\mathrm{F}^{2}$ & 1.020 \\
\hline Final R indices $[/>2 \sigma(l)]$ & $\mathrm{R} 1=0.0459 \mathrm{WR} 2=$ \\
& 0.1141 \\
\hline R indices (all data) & $\mathrm{R} 1=0.0742 \mathrm{WR2}=$ \\
\end{tabular}

\section{Computational Protocol}

All calculations were performed using Gaussian 09 suit of programs running under Linux or Windows $[35,36]$. Single point energy(SPE) calculations for the unrestricted triplet and BS singlet states of 1 at the experimental geometry were performed with B3LYP hybrid functional applying flexible triple-zeta 6-311G $(2 d, p)$ basis set. The magnetic exchange interaction between two magnetic sites 1 and 2 is given by Heisenberg spin Hamiltonian Equation 1. 


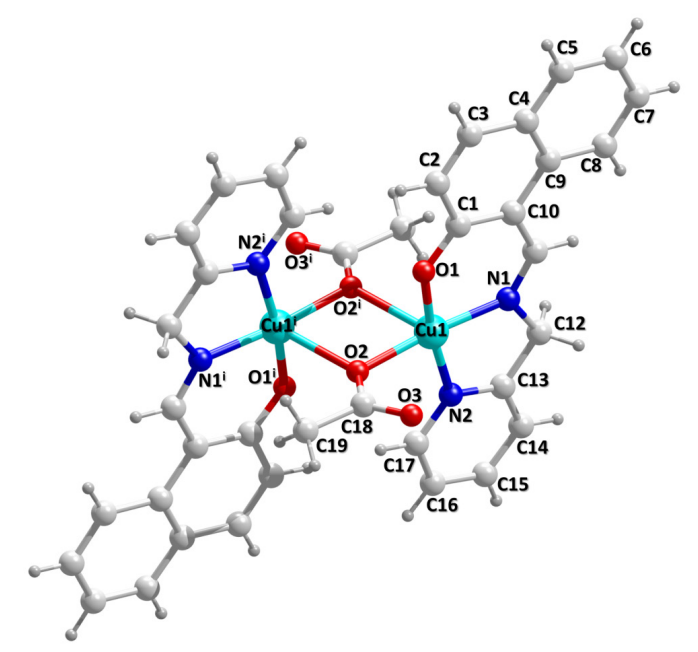

Figure 1. Symmetric Unit of 1.

$$
\hat{H}=-\hat{S}_{1} \times \hat{S}_{2}
$$

Where $\hat{\mathrm{S}}_{1}$ and $\hat{\mathrm{S}}_{2}$ are respective spin angular momentum operators. A positive values of coupling constant $J$ denotes to a triplet ground state which leads to ferromagnetic interaction while for negative values of $J$, the singlet state is lower in energy and leads to antiferromagnetic interaction. However correlation of such description with ab initio electronic structure calculations requires multi-determinantal methods and thus is computationally high demanding and not tolerable for large systems. Therefore the use of BS solution as an alternative approach with much less computational effort is mandatory in order to gain lowest energy singlet state. Using this methodology, the coupling constant is written as

$$
J=\frac{2\left(E_{B S}-E_{T^{1}}\right)}{1+S_{a b}^{2}}
$$

Where EBS is the electronic energy of BS singlet state and $E T^{\prime}$ is that of triplet state within unrestricted formalism using unperturbed BS orbitals. ET' can be approximated, in a single determinant approach, by the energy of actual triplet state owing to very less spin contamination. Based on the literature that once the magnetic orbitals are strongly delocalized where $S_{a b} \rightarrow 1$, the $\mathrm{BS}$ state becomes degenerate with pure singlet state [11] and Equation (2) is written as

$$
J=E_{B S}-E_{T}
$$

Consequently, we tentatively and preferably used Equation (3) in combination with B3LYP for the calculation of exchange coupling constant in 1 relying upon the successful quantitative results of related literature $[37,38]$.

\section{RESULTS and DISCCUSSION}

\section{Crystal Structure Description}

Molecular structure of 1 with the atom numbering scheme is given in Figure 1 (solvent methanol coexisting with symmetric unit within unit cell is omitted) and important bond lengths and angles are given in Table 2 . The geometry around each copper(II) center is best described as squarepyramidal (the structural index parameter, $\tau=0.038$ and is reasonably close to idealised square-pyramidal extreme [38]) constructed with the apical position occupied by $\mathrm{O} 2$ atom from one acetate and, with the basal plane which consists of $\mathrm{N} 1, \mathrm{~N} 2, \mathrm{O} 1$ atoms of tridentate NP and symmetryrelated $02^{i}$ atom from the other acetate. Bridging $\mathrm{O} 2$ and $\mathrm{O}^{\mathrm{i}}$ atoms simultaneously occupy both inplane and apical coordination sites of copper(II) nuclei within dimeric unit. The apical bond of bridging atom is as expected $0.49 \AA$ longer (Cu1O2i bond is $2.447 \AA$ and $\mathrm{Cu} 1-\mathrm{O} 2$ bond is 1.960 $\AA$ ) than the basal plane distance and is shorter than these in formerly studied five analogous structures [24,25-28]. The other in-plane bond distances are quantitatively comparable with corresponding values. The copper atom raised out of the plane by $0.062 \AA$ towards apical oxygen. 
Table 2. Important geometric parameters of 1 .

\begin{tabular}{|c|c|c|c|}
\hline Bonds $(\AA)$ & & Angles $\left(^{\circ}\right)$ & \\
\hline Cu1-01 & $1.906(3)$ & O1-Cu1-02 & $90.70(17)$ \\
\hline Cu1-O2 & $1.960(4)$ & O1-Cu1-N2 & $172.57(17)$ \\
\hline Cu1-N1 & $1.931(5)$ & O2-Cu1-N1 & 174.83(19) \\
\hline Cu1-N2 & $1.998(5)$ & O3-Cu1-N1 & $126.66(18)$ \\
\hline \multirow[t]{10}{*}{ Cu1-02(a) } & $2.447(4)$ & N1-Cu1-N2 & $82.45(2)$ \\
\hline & & 01-Cu1-03 & $83.45(19)$ \\
\hline & & 01-Cu1-02(a) & $92.87(15)$ \\
\hline & & O2-Cu1-N2 & $94.85(18)$ \\
\hline & & O3-Cu1-N2 & $96.41(19)$ \\
\hline & & N1-Cu1-O2(a) & $108.62(18)$ \\
\hline & & O1-Cu1-N1 & $91.8(2)$ \\
\hline & & O2-Cu1-03 & 49.19(14) \\
\hline & & O2-Cu1-O2(a) & $15.67(15)$ \\
\hline & & O3-Cu1-O2(a) & $124.54(13)$ \\
\hline
\end{tabular}

a: apical position

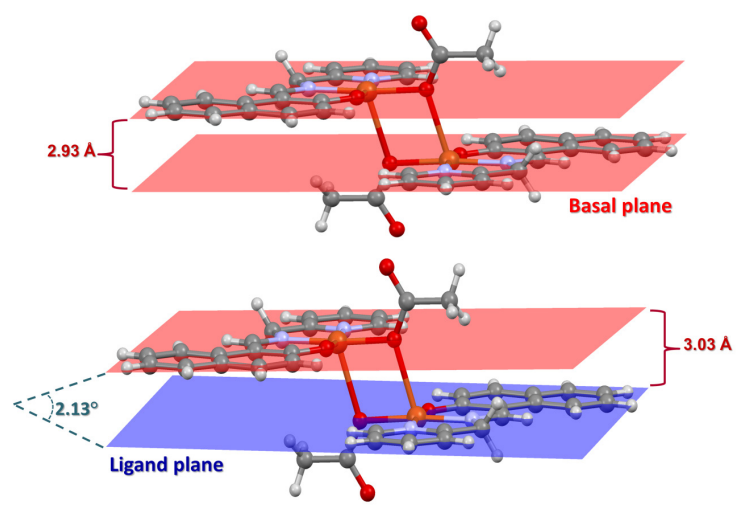

Figure 2. Least squares planes of 1 in symmetric unit (red: basal plane, purple: ligand plane).

For the sake of a plain comparison of 1 with analogous structures previously reported, the pivotal geometric parameters relating to basal plane from references 24-30 together with that of 1 were collected in Tables 3-4. Intermetallic separation in 1 is considerably greater than the former six structures and is slightly smaller than one in $\left[\mathrm{Cu}_{2}(5-\mathrm{Br}-\mathrm{L})_{2}(\mathrm{AC})_{2}\right]$ as inferred from Tables 3-4. It is also noteworthy in Tables 3-4 that the deviations of in-plane atoms from the basal plane in 1 are less than the corresponding values in all other structures. The smallest basal plane deviations of in-plane atoms of 1 as compared to these of other structures in references 2430 most probably relate to rigid planar array of NP ligand maintained by flat naphthalene ring since the base and the plane in which NP lies are almost coplanar solely with a deviation of $2.13^{\circ}$ as indicated in Figure 2. None of intra or intermolecular classical hydrogen bonds were encountered within crystal network. However, intermolecular $\mathrm{CH} . . . \pi$ and non-conventional hydrogen bonds pile up molecular units into $3 \mathrm{D}$ network. Piling of symmetric units through $a-b$ plane is shown in Figure 3. 
Table 3. Deviations of metal atoms from basal plane.

\begin{tabular}{|c|c|c|c|c|c|}
\hline Complex & $\begin{array}{l}\text { Bridging } \\
\text { angle }\left(^{\circ}\right)\end{array}$ & Deviation $(\AA)$ & $\mathrm{Cu} \bullet \bullet \mathrm{Cu}$ & Coup. & Ref \\
\hline$[\mathrm{Cu}(\mathrm{AE})(\mathrm{Ac})]_{2}$ & $95.34(5)$ & $0.0306(2)$ & $3.305(4)$ & Antiferro. & 24 \\
\hline$\left[\mathrm{Cu}_{2}(\mathrm{~L}) 2(\mathrm{Ac})_{2}\right]$ & 94.40 & -0.033 & 3.262 & No data & 25 \\
\hline$\left[\mathrm{Cu}_{2}(\mathrm{~L})(\mathrm{Ac}) 2\right] \cdot 2 \mathrm{MetOH}$ & $98.3(5)$ & 0.015 & $3.383(2)$ & Antiferro. & 26 \\
\hline$\left[\mathrm{Cu}_{2}\left(5-\mathrm{NO}_{2}-\mathrm{L}\right)_{2}(\mathrm{AC})_{2}\right]$ & $96.1(1)$ & -0.0154 & $3.409(1)$ & Antiferro. & 27 \\
\hline$\left[\mathrm{Cu}_{2}(5-\mathrm{Br}-\mathrm{L})_{2}(\mathrm{AC})_{2}\right]$ & $96.3(2)$ & 0.0296 & $3.506(1)$ & Antiferro. & \\
\hline$\left[\mathrm{Cu}_{2}\left(5-\mathrm{CH}_{3} \mathrm{O}-\mathrm{L}\right)(\mathrm{AC})_{2}\right] \cdot 2 \mathrm{H}_{2} \mathrm{O}$ & $98.1(3)$ & 0.004 & $3.384(3)$ & Antiferro. & 28 \\
\hline \multirow[t]{2}{*}[\mathrm{Cu}_{2}(\mathrm{L})_{2}(\mathrm{AC})_{2}]{$\cdot \mathrm{H}_{2} \mathrm{O} \cdot \mathrm{C}_{2} \mathrm{H}_{5} \mathrm{OH}^{*}$} & $95.7(1)$ & - & $3.445(1)$ & Ferro. & 29 \\
\hline & $102.6(1)$ & - & - & & \\
\hline (1) & $104.17(18)$ & $0.062(4)$ & $3.490(2)$ & No exc. & \\
\hline
\end{tabular}

AE: 7-amino-4-methyl-5-aza-3-hepten-2-onate, L(ref. 25): 2-((E)-(2((dimethylamino)ethylimino)methyl)-phenolate L(ref. 26): 2-[(2-aminoethyl)iminomethyl]phenolate, L(ref. 27): Dianion of $\mathrm{N}, \mathrm{N}^{\prime}$-bis(Z-((ohydroxybenzhydry1idene)amino)ethyl)1,2-ethanediamine, 5-NO2-L: anion of N-methyl-N'-( 5-nitrosalicylidene)-1,3-propanediamine 5-Br-L: anion of N-methyl-N'-(5-bromosalicylidene)-1,3-propanediamine, 5-CH30-L: anion of $\mathrm{N}$-(1,1-dimethyl-2-hydroxyethyl)salicylaldimine, $\mathrm{L}$ (ref.30): Dianion of $\mathrm{N}$-(1,1-dimethyl-2-hydroxyethyl)salicylaldimine.

*: Nonsymmetric complex with diffirent biridging angles and distances of two symmetrically different acetate bridges contrary to other analogous symmetric structures that are with symmetrically equivalent two acetate bridges.

Table 4. Deviations of coordinated atoms from basal plane.

\begin{tabular}{|c|c|c|c|c|c|}
\hline \multirow{2}{*}{ Complex } & \multicolumn{4}{|c|}{ Deviation $(\AA)$} & \multirow{2}{*}{ Ref. } \\
\hline & N1 & N2 & 01 & 02 & \\
\hline$[\mathrm{Cu}(\mathrm{AE})(\mathrm{Ac})]_{2}$ & $-0.125(2)$ & $0.157(2)$ & $0.101(1)$ & $-0.100(1)$ & 24 \\
\hline$\left[\mathrm{Cu}_{2}(\mathrm{~L})_{2}(\mathrm{AC})_{2}\right]$ & 0.144 & -0.124 & -0.123 & 0.136 & 25 \\
\hline$\left[\mathrm{Cu}_{2}(\mathrm{~L})(\mathrm{AC})_{2}\right] \cdot 2 \mathrm{MetOH}$ & 0.058 & -0.065 & -0.066 & 0.058 & 26 \\
\hline$\left[\mathrm{Cu}_{2}\left(5-\mathrm{NO}_{2}-\mathrm{L}\right)_{2}(\mathrm{Ac})_{2}\right]$ & -0.2239 & 0.2322 & 0.2472 & 0.2401 & \multirow{2}{*}{27} \\
\hline$\left[\mathrm{Cu}_{2}(5-\mathrm{Br}-\mathrm{L})_{2}(\mathrm{Ac})_{2}\right]$ & -0.1291 & 0.1455 & 0.1695 & -0.1563 & \\
\hline$\left[\mathrm{Cu}_{2}\left(5-\mathrm{CH}_{3} \mathrm{O}-\mathrm{L}\right)(\mathrm{AC})_{2}\right] \cdot 2 \mathrm{H}_{2} \mathrm{O}$ & 0.143 & 0.150 & 0.156 & 0.160 & 28 \\
\hline$(1)$ & -0.0116 & -0.0180 & -0.0194 & -0.0133 & \\
\hline
\end{tabular}

\section{EPR Spectral Study}

Figure 4 shows the EPR spectrum of 1 as expected for a powder sample. It displays usual anisotropic pattern belonging to $\mathrm{Cu}^{2+}$ ion $(\mathrm{S}=1 / 2$ $\mathrm{I}=3 / 2$ ), with $\mathrm{g}_{/ /}$and $\mathrm{g}$ peaks. The parallel peak is due to the fact that the external dc field is parallel to the symmetry axis of crystal field around the paramagnetic center. The perpendicular peak with high intensity also represents the fact that the external dc field is perpendicular to the symmetry axis of crystal field around the paramagnetic center. Hyperfine splitting could not be resolved due to line broadening caused by spin-orbital and spin-exchange interactions, because of the excessive spin concentration. The values of $g_{/ /}$and $g$ extracted from the powder spectrum are $\mathrm{g}_{\|}=2.217, \mathrm{~g}=2.053$, respectively, which are typical for square-pyramidal geometry of copper(II) ions. These g values suggest that the environment of $\mathrm{Cu}(\mathrm{II})$ ion has an elongated tetragonal axial symmetry with a (2B1g) ground state [39-42]. The deviation of the $g$ value from the free electron (2.0023) depends on the combined effects of ligand field and the spinorbit coupling [43]. Therefore, it can give us qualitative information about covalent nature of metal-ligand bonding. When the deviation gets smaller, covalent bonding becomes larger, or vice versa. This comparison is also being performed according to value of $\mathrm{g}_{/ /}=2.3$. Since the observed 


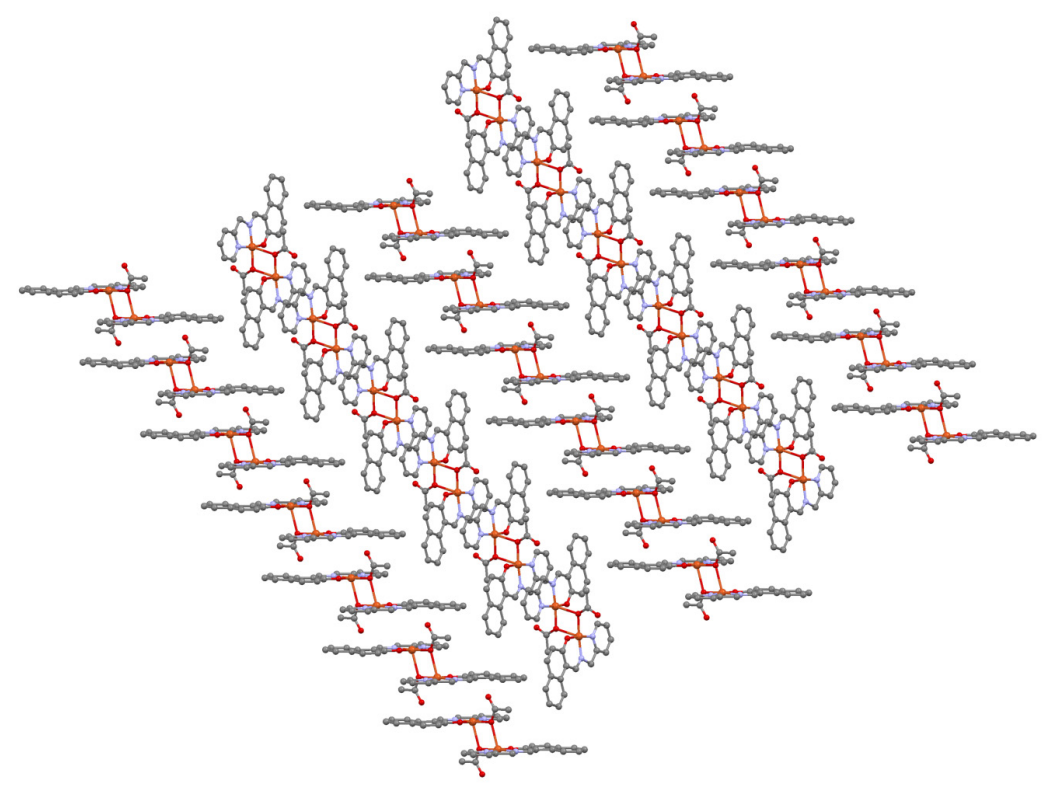

Figure 3. Packing diagram of 1 along a-b plane, displaying direction in which symmetric units interact with each other through $\pi-\pi$ bonding.

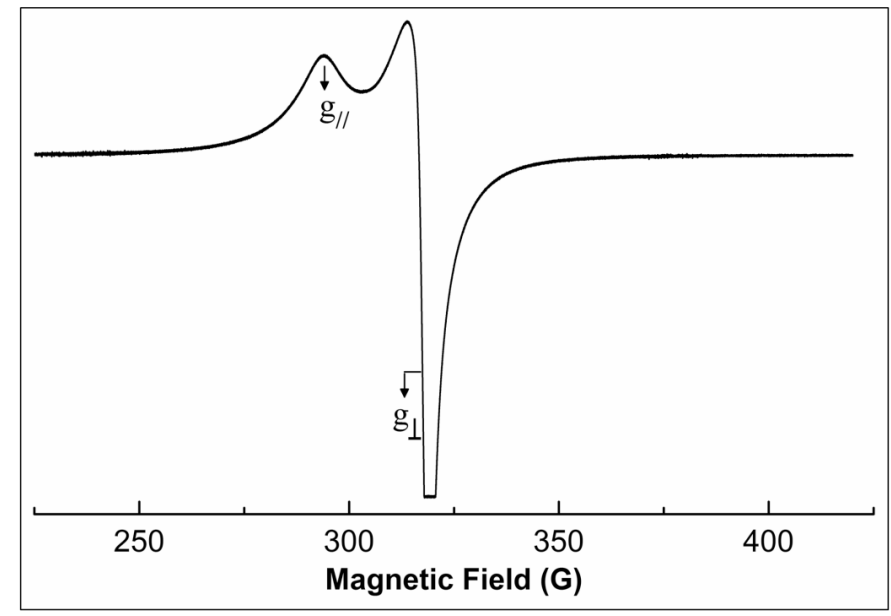

Figure 4. EPR spectrum for dried sample of 1.

value of $g_{/ /}$is less than 2.3, it shows covalent character of metal-ligand bonding in this complex [44]. Axial symmetry parameter $G$ calculated as is an indication of exchange interaction between two copper centers in solid complexes. If $G>4$ the exchange interaction is negligible, whereas when $G<4$, it indicates an appreciably interaction between copper centers [45-47]. The calculated $G$ value for this complex is greater than four for this complex suggesting that there is no interaction between metal ions in polycrystalline complex.

\section{Electronic Spectrum}

Electronic absorption spectrum of 1 (see $\mathrm{SI} 3$ in supporting information) displays a broad weak intensity maximum at around $618 \mathrm{~nm}$ and is characteristic of square pyramidal copper(II) environments [48-50]. Other strong $420 \mathrm{~nm}$ and $362 \mathrm{~nm}$ maxima are assigned as high intensity ligand to metal charge transfer transitions.

\section{DFT-BS Calculations}

Single point energy calculations were carried out at the experimental geometry for BS singlet and triplet states of 1 and, a small BS-singlettriplet energy gap of $3.51 \mathrm{~cm}^{-1}$ was found in favour of triplet state. Therefore, a weak negligible ferromagnetic exchange coupling was suggested by DFT-BS calculations in reasonably accordance with the experimental data. The predominance of 


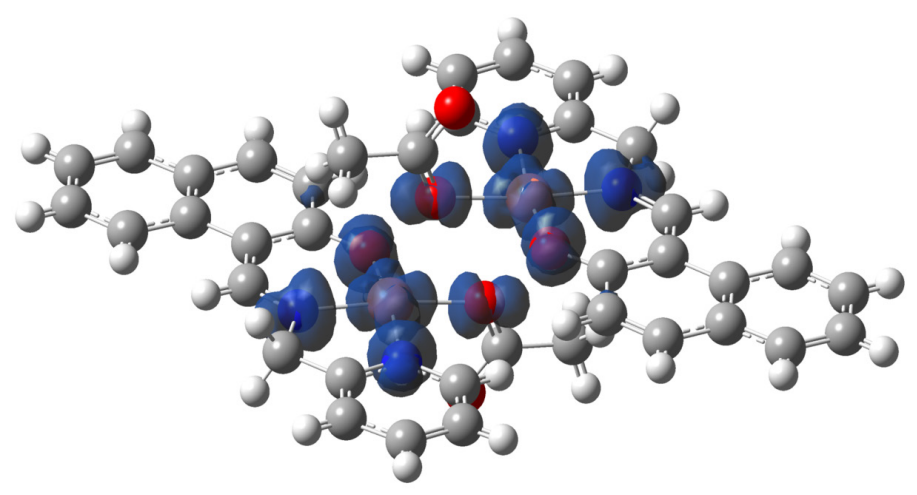

Figure 5. Magnetic spin orbitals of 1 for triplet state.

triplet spin state is also seen from the population of magnetic spin orbital relating to triplet state as depicted in Figure 5. Once Figure 5 is examined, spin orbital resides in planar array in basal planes and is strongly localized at paramagnetic copper(II) centers and hence, favours the expected inappreciable ferromagnetic exchange. Besides, very low spin densities at bridging atoms towards apical center atoms (0.0012 for out of plane copper(II), -0.017 for in-plane copper(II)) verify the proposed negligible exchange interaction. Two main geometric parameters namely intermetallic distance, and bridging angles that directly influence the type and magnitude of the exchange coupling are gathered together from references 24-30 in Tables 3-4. As seen in Table 3 all the complexes magnetically studied previously were shown to be weakly ferro and antiferromagnetic while 1 displays none of permanent exchange coupling. Actually within tolerable computational expense, magnetostructural studies were conducted dependently on these two parameters solely within $3.31-3.73 \AA$ and $101-108^{\circ}$ ranges respectively for 1 and the exchange interactions in the whole range were remained unchanged.

\section{CONCLUSION}

A single and new member of mono-atom acetatebridged dinuclear symmetric Schiff base complex of copper(II) has been prepared successfully and fully characterized by X-ray crystallography and Elemental analyses, IR, UV-Vis, LC-MS/MS techniques. Magnetic behaviour of the complex has been examined experimentally through EPR and an insignificant ferromagnetic exchange coupling was exhibited. Whereas, it has been mentioned before that all analogous structures previously reported have shown magnetic exchange. Apart from its former counterparts, we have attributed this uncommon behaviour of title complex to rigid planar structure of Schiff base ligand compelling the coplanarity of ligand and basal plane. Since strong spin localization take places in the base $\mathrm{CuN}_{2} \mathrm{O}_{2}$ core rather than bridging $\mathrm{Cu}_{2} \mathrm{O}_{2}$ core which often induces antiferromagnetic exchange pathway in these type $b$ dimers. The proposed magnetic behaviour of the complex was also supported successfully by DFT-BS calculations. On the other hand, magnetism-structure relationship has been also investigated for the complex within given range of intermetallic distance and bridging angle and none of noteworthy exchange has been encountered in calculated data. Consequently and as far as we know, a single paramagnetic symmetric Schiff base-copper(II) complex with mono-atom acetate-bridged has been synthesized among its counterparts and fully characterized in the study reported herein.

\section{ACKNOWLEDGEMENT}

Trabzon Forensic Medicine Institution is acknowledged for its support for ESI-MS measurements conducted by forensic chemist Özgür Turna.

\section{SUPPLEMENTARY MATERIAL}

CCDC 1015118 contains the supplementary crystallographic data for this paper. These data can be obtained free of charge from The Cambridge Crystallographic Data Center via http://www.ccdc.cam.ac.uk/data_request/cif. 


\section{References}

1. K.D. Karlin, Z. Tyeklar, Bioinorganic Chemistry of Copper, Chapman and Hall, New York, (1993).

2. L.Q. Jun, A.E. True, Prog. Inorg. Chem., 38 (1990) 97.

3. C.Y. Chen, J.W. Lu, H.H. Wei, J. Chin. Chem. Soc., 56 (2009) 89.

4. M. Lubben, R. Hage, A. Meetsma, K. Bÿma, B.L. Feringa, Inorg. Chem., 34 (1995) 2217.

5. O. Kahn, Molecular Magnetism, Weinheim, Germany (1993).

6. N. Palanisami, G. Prabusankar, R. Murugavel, Inorg. Chem. Commun., 9 (2006) 1002.

7. R. Baggio, R. Calvo, M.T. Garland, O. Pena, M. Perec, L.D. Slep, Inorg. Chem. Commun., 10 (2007) 1249.

8. S.K. Dey, B. Bag, K.M. Abdul Malik, M.S. El Fallah, J. Ribas, S. Mitra, Inorg. Chem., 42 (2003) 4029.

9. A. Elmali, C.T. Zeyrek, Y.J. Elerman, J. Mol. Struct., 693 (2004) 225.

10. L.C.W. Baker, L. Lebioda, J. Grochowski, H.G. Mukherjee, J. Am. Chem. Soc., 102 (1980) 3276.

11. E. Ali Md., S.N. Datta, J. Mol. Struct.: Theochem, 775 (2006) 19.

12. P. Gentschev, M. Lüken, N. Möller, A. Rompel, B. Krebs, Inorg. Chem. Commun., 4 (2001) 753.

13. F.P.W. Agterberg, H.A.J. Provó Kluit, W.L. Driessen, J. Reedijk, H. Oevering, W. Buijs, N. Veldman, M.T. Lakin, A.L. Spek, Inorg. Chim. Acta, 267 (1998) 183.

14. O.R. Nascimento, L.M.B. Napolitano, M.H. Torre, O. Pena, R.J. Calvo, Braz. Chem., Soc. 22 (2011) 669.

15. R. Baggio, M.T. Garland, J. Manzur, O. Pena, M. Perec, E. Spodine, A. Vega, Inorg. Chim. Acta., 286 (1999) 74.

16. G. Christou, S.P. Perlepes, E. Libby, K. Folting, J.C. Huffman, R.J. Webb, D.N. Hendrickson, Inorg. Chem., 29 (1990) 3657.

17. A. Mukherjee, M.K. Saha, M. Nethaji, A.R. Chakravarty, Polyhedron, 19 (2004) 2177.

18. B. Bleaney, K.D. Bowers, Proc. Roy. Soc., A214 (1951) 451.

19. J.N. Van Niekerk, F.R.L. Schoening, Acta Cryst., 6 (1953) 227.

20. K.Y. Choi, Korean J. Crystallogr., 17 (2006) 46.

21. K.Y. Choi, S-.Y. Park, A-.K. Shin, J. Chem. Crystallogr., 36 (2006) 7.

22. P.Y. Boukari, Acta Cryst., B38 (1982) 2458.

23. G.B. Deacon, R.J. Phillips, Coord. Chem. Rev., 33 (1980) 227.

24. J.P. Costes, F. Dahan, J-.P. Laurent, Inorg. Chem., 24 (1984) 1018.

25. C.C. Zhao, Y-.B. Jiang, A-.L. Cui, H-.Z. Kou, Acta Crystallogr. Sect., 63 (2007) 1824.

26. B. Chiari, W.E. Hatfield, O. Piovesana, L.W. Ter Haar, P.F. Zanazzi, Inorg. Chem., 22 (1983) 1468.

27. B. Chiari, J.H. Helms, O. Piovesana, T. Tarantelli, P.F. Zanazzi, Inorg. Chem., 25 (1986) 2408.

28. B. Chiari, J.H. Helms, O. Piovesana, T. Tarantelli, P.F. Zanazzi, Inorg. Chem., 25 (1986) 870.

29. A.M. Greenaway, C.J. O'Connor, J.W. Overman, E. Sinn, Inorg. Chem., 20 (1981) 1508.

30. H. Liu, F. Gao, D. Niu, J. Tian, Inorg. Chim. Acta, 362 (2009) 4179.

31. J. Xian, Z-.L. You, M. Zhang, M. Hou, X-.H. Li, J. Coord. Chem., 64 (2011) 3265.
32. L. Noodleman, L. Case, Adv. Inorg. Chem., 38 (1992) 423.

33. E. Ruiz, J. Cano, S. Alvarez, P. Alemany, J. Comput. Chem., 20 (1999) 1391.

34. G.M. Sheldrick, Acta Crystallogr., A64 (2008) 112.

35. Gaussian 09, Revision A.1, M.J. Frisch, G.W. Trucks, H.B. Schlegel, G.E. Scuseria, M.A. Robb, J.R. Cheeseman, G. Scalmani, V. Barone, B. Mennucci, G.A. Petersson, H. Nakatsuji, M. Caricato, X. Li, H.P. Hratchian, A.F. Izmaylov, A.F. Bloino, G. Zheng, J.L. Sonnenberg, M. Hada, M. Ehara, K. Toyota, R. Fukuda, J. Hasegawa, M. Ishida, T. Nakajima, Y. Honda, O. Kitao, H. Nakai, T. Vreven, J.A. Montgomery, J.E. Peralta Jr., F. Ogliaro, M. Bearpark, J.J. Heyd, E. Brothers, K.N. Kudin, V.N. Staroverov, R. Kobayashi, J. Normand, K. Raghavachari, A. Rendell, J.C. Burant, S.S. Iyengar, J. Tomasi, M. Cossi, N. Rega, J.M. Millam, M. Klene, J.E. Knox, J.B. Cross, V. Bakken, C. Adamo, J. Jaramillo, R. Gomperts, R.E. Stratmann, O. Yazyev, A.J. Austin, R. Cammi, C. Pomelli, J.W. Ochterski, R.L. Martin, K. Morokuma, V.G. Zakrzewski, G.A. Voth, P. Salvador, J.J. Dannenberg, S. Dapprich, A.D. Daniels, Ö. Farkas, Ö. Foresman, J.V. Ortiz, J. Cioslowski, D.J. Fox, Gaussian, Inc., Wallingford CT, (2009).

36. M.J. Frisch, G.W. Trucks, H.B. Schlegel, P.M.W. Gill, B.G. Johnson, M.W. Wong, J.B. Foresman, J.B. Robb, M. Head-Gordon, E.S. Replogle, R. Gomperts, J.L. Andres, K. Raghavachari, J.S. Binkley, C. Gonzalez, R.L. Martin, D.J. Fox, D.J. Defrees, J. Baker, J.J.P. Stewart, J.A. Pople, Gaussian 92/DFT, Revision F.2; Gaussian, Inc.: Pittsburgh PA, (1993).

37. A. Rodríguez-Fortea, P.Alemany S. Alvarez, E. Ruiz, Chem. Eur. J., 7 (2001) 62.

38. A.W. Addison, T.N. Rao, J. Reedijk, J. Van Rijn, G.C. Verschoor, J. Chem. Soc. Dalton Trans. (1984) 1349.

39. R.J. Dudley, B.J. Hathaway J. Chem. Soc., A 12 (1970) 2799.

40. E. Di Mauro, S.M. Domiciano, J. Phys. Chem. Solids, 60 (1999) 1849.

41. Y. Yerli, S. Kazan, O. Yalçın, B. Aktas Spectrochim. Acta Part A, 64 (2006) 642.

42. Y. Yerli, F. Köksal A. Karadag Solid State Sci., 5 (2003) 1319.

43. C.J. Ballhausen Introduction to Ligand Field Theory, McGraw-Hill, New york, (1962).

44. D. Kivelson and R. Neiman, J. Chem. Phys., 35 (1961) 149.

45. I.M. Procter, B.J. Hathaway P. Nicholis, J. Chem. Soc. Dalton Trans., (1968) 1678.

46. J.J. Earney, C.P.B. Finn, B. M. Najafabadi, J. Phys. C: Solid St. Phys., 4 (1971) 1013.

47. B.J. Hathaway, D.E. Billing, Coord. Chem. Rev., 5 (1970) 143.

48. B.J. Hathaway, Comprehensive Coordination Chemistry; G. Wilkinson, R.G. Gillard, J.A. McCleverty (eds.); Pergamon Press, Oxford, England, 5 (1987) 533.

49. G.A. McLachlan, G.D. Fallon, R.L. Martin, L. Spiccia, Inorg. Chem., 34 (1995) 254.

50. N. Wei, N.N. Murthy, K.D. Karlin, Inorg. Chem., 33 (1994) 6093. 
